\title{
AMINU DRAMANI \\ State intervention and the labyrinth of communal conflict in Ghana: How Kwame Nkrumah missed the opportunity to address the Bawku conflict
}

\begin{abstract}
Most scholarly accounts assert that governments' conflict resolution and peacebuilding efforts fail to address the root causes, prolong, or worsen the conflict situation. This supposed failure arises mainly because state actors pursue strategic interests in the peace processes, which provokes adversarial inter-and intra-group relations, especially in Africa where communal conflicts remain a great threat to economies and security. Nonetheless, the discussions fail to adequately investigate the details of state interventions and how they affect the potential for peace in some notorious conflict-affected areas. This paper examines how the Opoku-Afari Committee Report, the government of Ghana's first official response to the Bawku conflict in 1957, protracts and further complicates the conflict. Employing qualitative thematic analysis of historical documents, in-depth interviews, and observation, we argue that the failure by the Nkrumah-backed committee to provide a sustained solution to the Bawku conflict is rooted in three dimensions: the committee's failure to engage some important history of Bawku; the portrayal of Bawku as outside of Nayiri's jurisdiction; and the promotion of a cultural dichotomy (othering) between the Kusasi and Mamprusi. These findings further the existing knowledge on the conflict by drawing out specifics of the state failure which are usually obscured in the literature.
\end{abstract}

Keywords: Bawku conflict; state intervention; peacebuilding; conflict resolution; communal conflict.

\section{Introduction}

States' intervention in intrastate communal conflicts is usually rooted in the interest to entrench power and gain strategic benefits to state actors and allies than address the root causes of the conflict. ${ }^{1}$ Communal conflict here refers to violent conflict between non-state actors that are organised along shared communal identity. It excludes purely interpersonal conflicts and those in which the state is involved as an active conflict party. Such conflicts are between groups that are divided and mobilised along identity lines and use violence to gain control over the conflict issues, particularly indivisible resources such as land and local political power. The basis of such divisions

\footnotetext{
${ }^{1}$ S. Gates, H. Harvard, P.J. Mark, and S. Havard, 'International inconsistency and political instability: polity duration, 1800-2000', American Journal of Political Science, 50:4 (2006), 893-908.
} 
may be ethnic, religious and or indigeneity. ${ }^{2}$ Given its monopoly over the legitimate use of force within its territory ${ }^{3}$, the state, thus the government is expected to play critical roles to sustainably address communal conflicts that affect their jurisdictions. Nonetheless, it is argued that about onethird of communal conflicts, mostly in Sub-Saharan Africa see little sustained intervention by central governments which usually use heavy-handed security and top-down approaches with strategic interest. ${ }^{4}$ This mostly fuels the conflicts leading to protraction and intractable conflict situations. ${ }^{5}$ While some governments intervene with interest and worsen the conflict situation, others make no concerted efforts at all. ${ }^{6}$ For instance, Emma Elfversson opines that more than onethird of communal conflicts reaching an intensity of at least 25 battle-related deaths per year, in sub-Saharan Africa in 1989-2010, receive no security force deployment by governments. ${ }^{7}$

This state-culpability in communal conflicts is especially emboldened by (neo) patrimonial politics which exacerbates group conflicts ${ }^{8}$ and encourages the proliferation of and support for tribal militias, for instance, in Sudan and South Sudan. ${ }^{9}$ This explains why in Africa, ethnic constituencies and control over local power and resources are key issues surrounding power

\footnotetext{
${ }^{2}$ Elfversson, 'Providing Security', 792-794.

${ }^{3}$ T. Waters, 'Politics as a vocation by Max Weber', in T. Waters and D. Waters (eds.), Weber's Rationalism and Modern Society (New York, 2015), 136.

${ }^{4}$ E. Elfversson, 'Providing security or protecting interests? government interventions in violent communal conflicts in Africa', Journal of Peace Research, 52:6 (2015), 271.

${ }^{5}$ I. Abdulrahman and U. A. Tar, 'Conflict management and peacebuilding in Africa: the role of state and non-state agencies', Information, Society and Justice, 1:2 (2008), 185-202; S. I. Wilkinson, 'Communal violence in India', Economic and Political Weekly, 40:44/45 (2005) 4768-4770; I. M. Enwerem, 'An assessment of government's formal responses to ethnic/religious riots, 1980-1990s', in E. E. Uwezie, I. O. Albert and G. N. Uzoigwe (eds.), Inter-Ethnic and Religious Conflict Resolution in Nigeria (Lanham, 1999), 121-134.

${ }^{6}$ E. Johansson, 'Managing Communal Conflicts: The Role of the State'. Paper presented at the $52^{\text {nd }}$ Annual Convention of the International Studies Association, Montreal, (March 2011) 16-19. (http://www.academia.edu/720046/Emma_Johansson_Managing_Communal_Conflicts_The_Role_of_the_State), $30 / 12 / 2020$.

7ibid, 793.

${ }^{8}$ U. B. Ikpe. 'The patrimonial state and inter-ethnic conflicts in Nigeria'. Ethnic and Racial Studies 32(4), 679-697.

${ }^{9}$ S. E. Hutchinson, 'A curse from God? religion and political dimensions of the post-1991 rise of the ethnic violence South Sudan', Journal of Modern African Studies, 39:2 (2001), 309-331.
} 
politics and violent conflicts. ${ }^{10}$ Post-colonial African states are deemed weak characterised by 'thin' security forces, poor economies, and less integrated systems. This creates and is sustained by patrimonial and clientelist network politics in most parts of the continent which weaken the prospects to address conflicts and fight crime in in a sustained manner. ${ }^{11}$ Although the strategic interests or failures of state interventions in conflicts vary significantly, the recurrence of communal conflicts in sub-Saharan Africa has generally disrupted local livelihoods, economies, and political systems, and caused sub-national, national and regional instability through spillover effect. $^{12}$

Although hailed as a beacon of democracy in Africa, Ghana is one of the many countries that are shrouded with some difficult communal conflict situations that reflect in the debates about state intervention and ineffective handling of communal conflict. A major communal conflict that dominates scholarly and policy discourses on Ghana is the Bawku chieftaincy conflict. Bawku, a municipality in the north-eastern corner of Ghana, is a site of a long-standing conflict dating back to British colonialism in the 1930s over who has the legitimate right to rule the area. At the heart of the conflict is the 'Bawku Skin' ${ }^{13}$ It is a traditional power struggle between the two major ethnic groups in the area, the Mamprusi,, and the Kusasi. This conflict is intermittent and long-standing and has resulted in the loss of human lives and properties for over six decades. Just before and immediately after independence, the conflict took a dangerous turn, culminating into the first direct clash occurring immediately after Ghana's independence in 1957. As a result, the then Governor-

\footnotetext{
${ }^{10} \mathrm{E}$. Elfversson, 'Providing security', 791-805.

${ }^{11}$ R. Jackson, 'Violent internal conflict and African state: towards a framework of analysis', Journal of Contemporary African Studies, 20:1 (2002), 29-52; L. E. Cederman, A. Wimmer and B. Min, 'Why do ethnic groups rebel? New data and analysis', World Politics, 62:1 (Cambridge, 2010), 87-119.

${ }^{12}$ Elfversson, 'Providing Security', 792

${ }^{13}$ Skin is the symbol of traditional authority in northern Ghana, equivalent to the stool in the south part of the country. When a chief is enskinned, he is seated on the Skin of a wild animal like an ox sacrificed for the occasion. Northern chiefs sometimes sit on a pile of Skins. It is therefore customary in Ghana to refer to the Skin polities of the North where chiefs are 'enskinned' (the processes of coronation) rather than 'enstooled', as is the case in southern Ghana.
} 
General, Lord Listowel, in consultation with Kwame Nkrumah, the Prime Minister, set up the Opoku-Afari Committee to investigate the conflict. The committee's report forms the government's first formal response to the Bawku Skin conflict in 1957.

This study aims to interrogate the report alongside theoretical and empirical evidence to establish how the first state intervention affects the dynamics of the conflict in contemporary times. We examine the Opoku-Afari Committee Report of the Convention People's Party C.P.P. government's intervention in the Bawku Skin conflict, which was intended to address the root cause of the conflict. While other actors have been active in addressing the Bawku conflict, especially NGOs and other non-state organizations and actors, our focus on state (and the first official) response helps to understand how the subsequent manifestations of the violence and the ineffectiveness of successive peacebuilding efforts. We demonstrate that Ghana's experience with communal conflicts reflects significantly in the literature on other parts of Africa and in the global South - mainly the culpability of the state and political actors in the complexity and protraction of conflicts. Yet, an analysis of Ghana's intervention in communal conflicts exposes key details that are lacking in existing knowledge.

Generally, research on communal conflicts has focused mainly on the causes and dynamics with little attention to responses to the detailed direct responses by conflict partners to state intervention. ${ }^{14}$ Some accounts have investigated the causes and dynamics of the Bawku local political power (chieftaincy) conflict. However, the literature fails to comprehensively analyse how the conflict was handled when it first broke out in1957 and how that has influenced the management of the conflict by subsequent Ghanaian governments and politicians. Besides, the

\footnotetext{
${ }^{14}$ O.M. Theisen, 'Climate clashes? Weather variability, land pressure, and organized violence in Kenya, 19892004'. Journal of Peace Research, 49(1), 81-96; C. Raleigh, 'Political marginalization, climate change, and conflict in Africa Sahel states.' International studies Review, 12(1), 69-86.
} 
accounts that cited the culpability of the first state intervention, do not adequately identify the details of the committee report and how they've negatively affected prospects for peace in the traditional area. This paper does not pass judgement but rather only critically analyses the committee's report in the light of the existing theories in peace and conflict.

To adequately examine the details of how the first state intervention in the Bawku conflict affected the peacebuilding conflict dynamics, the rest of the paper is structured into five parts. The first presents the methods of the study involving a case study design and qualitative data collection and analysis using interviews, documentary analysis, and observations. The second part provides a brief background to the 1957 clash while the third delves into the Opoku-Afari's committee report: composition, recommendation, and the reactions of adversaries. The fourth part subsequently presents the key extracts from the Committee report and how they affect recurrent conflicts and peacebuilding efforts. In the fifth part, the evidence which informed the committee's recommendations is examined.

\section{Research methods}

A case study design and qualitative research approach were employed for this research. Data for this study was part of a broader original study that investigated the ramifications of dormant lowintensity conflicts in Ghana, using the Bawku chieftaincy conflict as a case study. The case study approach uses a relatively small size research context which allows for the use of multiple techniques to gather in-depth data from a specific context over a period ${ }^{15}$. Field data collection involved semi-structured, in-depth interviews, documentary analysis, and observation for seven months (September 2018 to March 2019). The interviews centered on respondents' perception

\footnotetext{
${ }^{15}$ R. K. Yin, Case Study Research: Design and Methods (5th ed.). (USA, SAGE Publications, Inc., 2014), 370.
} 
about how the first committee's report and subsequent dynamics in the Bawku conflict and peacebuilding efforts. Although some interlocutors were identified by snowballing, they were mainly selected using the purposive sampling technique. Bryman describes the purposive sampling technique as a deliberate action taken in specific studies to reach out to respondents who are capable of providing in-depth information about the problem being studied ${ }^{16}$. In all, 39 qualitative interviews were conducted.

Interviews were conducted with the traditional rulers of the Mamprusi and the Kusasi ethnic groups; leaders of four other settler ethnic groups, namely, the Hausa, Dagomba, Moshie, and the Bissa. Others were personnel of the security agencies, some members of the Bawku InterEthnic Peace Committee (BIEPC), traders, the national president of the Bissa Youth Association, ordinary community members, teachers and directors of civil society and non-governmental organizations that are directly or indirectly involved in the Bawku peace process. The consent of all interlocutors was duly obtained before conducting the interviews. The study observed ethical considerations including informed consent, confidentiality, voluntary participation of interlocutors and approval before recording the interviews and conversations. Where audio recording was not approved, notes were hand-written. Other primary sources used were documents containing court and National House of Chiefs rulings on the conflict and unpublished manuscripts on the Bawku conflict, archival materials relating to the conflict, committee reports, and memos. These were supplemented by secondary sources from published books, unpublished manuscripts, reports, and journal articles. This study made meanings from the data through narrations, inferences, descriptions, and direct quotations in the discussions. Discussions of the report was supported with responses of the primary actors in the conflict and /or those of the other settler groups. Where there

${ }^{16}$ A. Bryman, Social Research Methods, (Oxford University Press, 2015). 
was conflict of ideas of the primary actors, the views of the other ethnic groups, particularly the Hausa, Dagomba, Moshis and the Bissa were sought. The qualitative data gathered were analysed through content analysis of emerging themes. This is a systematic method for analysing textual information in a standardised way that allows the researcher to make inferences about that information.

\section{Brief background to the 1957 clash}

Two entwined factors explain the history and protraction of the Bawku conflict, and by extension, northern Ghana conflicts: colonial legacy and post-colonial politics. First, the conflicts in northern Ghana are mostly traced to the impact of colonialism on inter-ethnic relations and its encroachment on the traditional governance system ${ }^{17}$. For its convenience, the British colonial administration (hereinafter referred to as the British) intruded and (attempted to) eroded the chieftaincy institution in the whole of the North and across the Gold Coast (now Ghana). Writing about British administration in the coastal states and the threat posed to the chieftaincy institution, Irene Odotei relates:

The British had the aim of encroachment on the political sovereignty of chiefs in the colony. By the time the British formally declared the Gold Coast a colony in 1874, chiefly authority at least in the coastal states or states south of Asante was under considerable threat and erosion. ${ }^{18}$

\footnotetext{
${ }^{17}$ Steven Kendie, 'Conflict management and peacebuilding for poverty reduction'. Proceedings of the 2010 harmattan school, (GILLBT Press, Tamale); A. K. Awedoba. An ethnographic study of Northern Ghanaian conflicts: Towards a sustainable peace (Saharan Publishers, 2010).

${ }^{18}$ I. Odotei "Chieftaincy Politics in Ghana: Historical Dimensions." in Vaughan, Olufemi (ed) Indigenous Political structures and Governance in Africa. (Ibadon, Sefer Books Ltd., 2003), 325. Note also that 'Fetu' is an ethnic group in Ghana.
} 
The situation was no different in the Northern Territories (present-day Northern Ghana). In the Upper East Region in general and Mamprugu in particular, the British colonial administration, for its administrative convenience and to exert control over the overlord of Mamprugu (the Nayiri), employed unilateral measures including renaming parts of the Mamprugu area and re-designating the ethnic groups therein who already had their identities. ${ }^{19}$

Figure 1. Map of zotinga

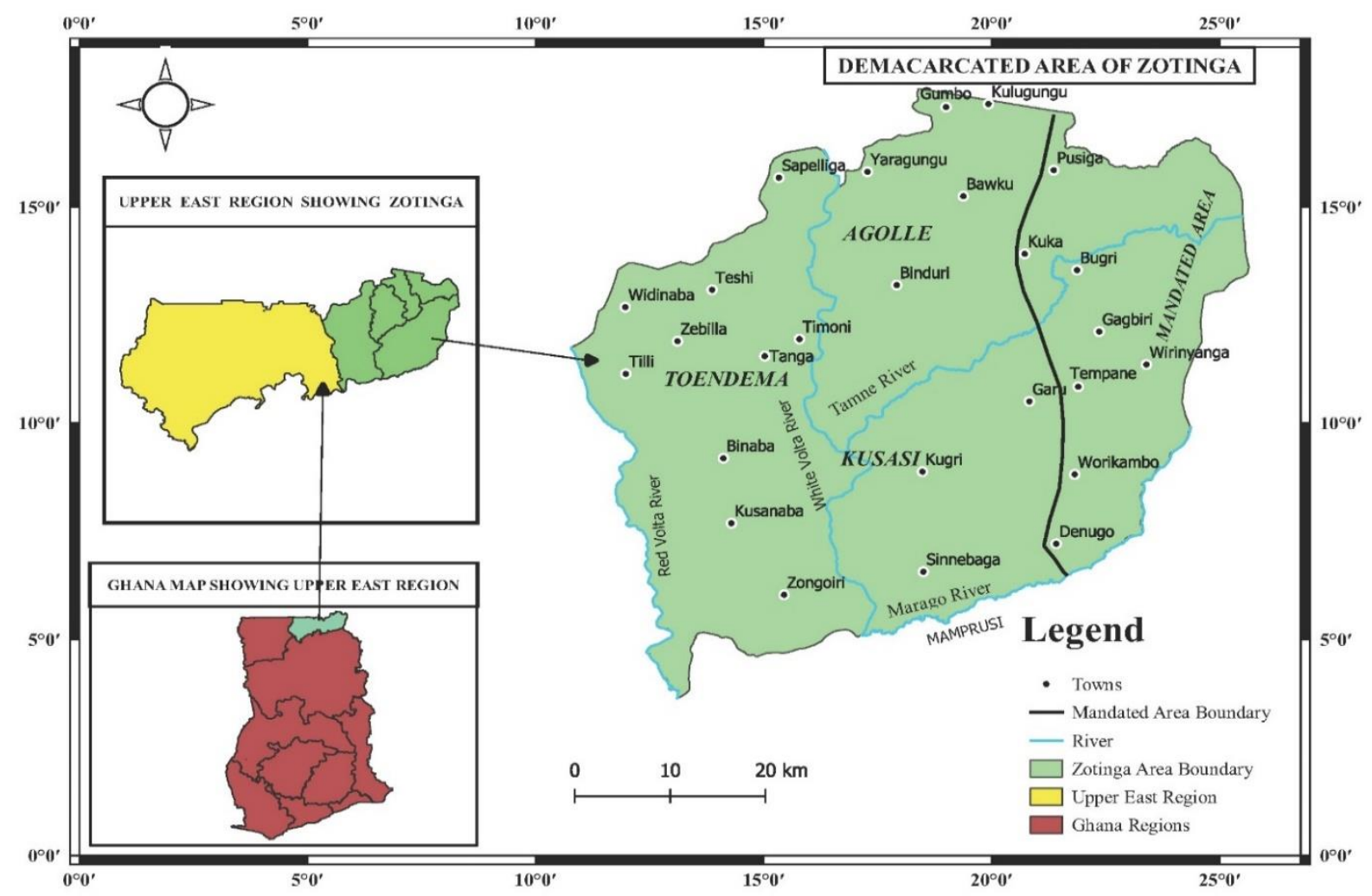

Source: Yirimea, 2009.

For instance, Zotinga (which covered the Bawku East Municipal area, the Bawku West and the Garu-Tempani Districts, see figure 1) was renamed Kusasi and Moaduri as Frafra ${ }^{20}$, an action that the Mamprusi in particular felt bitter about. It created the erroneous impression that the Kusasis

\footnotetext{
${ }^{19}$ Nayiri is the paramount chief of all Mamprusi in Ghana. He is headquartered in Nalerigu in the Northern Region of Ghana. Bawkunaba is the paramount chief of the Bawku Traditional Area.

${ }^{20}$ Moaduri is one of the six (6) districts in the North East Region of Ghana, created in 2012. Yagaba is its capital.
} 
and the Frafra were the majority in Zotinga and Moaduri respectively. By so doing, the colonial administration left a legacy of tension between the Kusasi and the Mamprusi in particular as it created a seeming Kusasi majority in Zotinga. This 'legacy' rolled on to the post-colonial era.

The first research into the customs, traditional institutions, ethnological and historical relations among the tribes in Northern Ghana by the British colonial administration was in 1931 by Rattray, which copiously confirms the colonial manipulation of ethnic composition mainly through the British flagship Indirect Rule. Thus, the genesis of the Mamprusi-Kusasi chieftaincy conflict in Bawku can be traced to the British colonial administration in the Northern Territories. ${ }^{21}$

Apart from colonialism, other events, immediately before and after Ghana's independence, further polarized the Kusasi and the Mamprusi ethnic groups to the point of violent confrontation. Electoral politics divided the Mamprusi and the Kusasi into pro-NPP and pro-CPP factions respectively. In the run-up to the 1954 elections, the north became heavily polarized along ethnic and partisan lines. ${ }^{22}$ While the Mamprusi supported the Northern People's Party (N.P.P), the Kusasi supported the Convention People's Party (C.P.P.). As a political strategy of securing political control in the north, Nkrumah and the C.P.P systematically undermined the Nayiri and weakened the N.P.P by infiltrating the satellite Mamprusi colonies such as the Frafra and Kusasi communities as well as intimidating and harassing Mamprusi chiefs and elders ${ }^{23}$. Local C.P.P supporters in the area incited the Kusasi to initiate calls for secession from Mamprusi rule. ${ }^{24}$ From 1954 onwards the Mamprusi and the Kusasi became sharply divided along ethnic, partisan political and chieftaincy lines, reflecting not only local but also national politics. Therefore, when Nkrumah

\footnotetext{
${ }^{21}$ P. Ladouceur, Chiefs and Politicians: The Politics of Regionalism is Northern Ghana (London, 1979), 114

${ }^{22}$ C. Lund, 'Bawku is still volatile': ethno-political conflict and state recognition in northern Ghana', The Journal of Modern African Studies, 41:4 (2003), 587-610.

${ }^{23}$ F.Y.T. Longi, 'If Nkrumah and the C.P.P did not come on to the scene, the Mamprusi - Kusasi Conflict', The International Journal of Humanities and Social Studies, 3:1 (2015), 27 -33.

${ }^{24}$ Interview with Seidu Abagri
} 
become the Prime Minister of Ghana in 1957 and intensified his efforts to greatly increase C.P.P.'s political dominance in the north by reducing the influence of the Nayiri and frustrating the N.P.P., the Kusasi became emboldened waiting for the opportunity to enskin their kind as the Bawkunaba (the overlord of the Bawku Traditional Area).

The death of the then Bawkunaba, Na Awuni (a Mamprusi), in December 1956 and the misunderstanding that broke out among the qualified Mamprusi princes after the Nayiri's choice of Yirimea Mahama as the next Bawkunaba provided that opportunity for the Kusasi. With the support of some C.P.P. youth and the disappointed Mamprusi princes, the Kusasi enskinned Abugarago Azoka as a parallel Bawkunaba, in $1957 .{ }^{25}$ This parallel enskinment created the Mamprusi-Kusasi imbroglio when Azoka was officially recognised as Bawkunaba. There was heavy loss of lives and destruction of property in the ensuing clashes. As a result, the Governor General, Lord Listowel, in consultation with the Prime Minister, Nkrumah, appointed a threemember Committee of Enquiry, chaired by S. D. Opoku-Afari ${ }^{26}$, to investigate the causes of the clashes and make recommendations.

\section{The Opoku-Afari Committee: Composition and reactions of adversaries}

The three-member Committee set up by the government comprised Opoku-Afari, a legal luminary and chairman; Nana Yaw Agyemang Badu, the then king of Dormaa, in Brong Ahafo and Lure Kanton III, chief of Tumu Koro. All three were known to be pro-C.P.P. For example, in the 1954 election, Lure Kanton III openly campaigned for Imoro Egala who was Nkrumah's choice for the Legislative Assembly. The partisan nature of the committee became overt when it got directly

\footnotetext{
${ }^{25}$ Abugrago is a Kusasi, whose father, Azoka (a soothsayer), migrated from Pusisga to Bawku and eventually settled with the Mamprusi. After his father's death, Abugrago was retained in the Mamprusi palace as a servant and later the Mamprusi king's sandals bearer.

${ }^{26}$ Opoku-Afari was a lawyer and a C.P.P sympathiser.
} 
involved in a legal struggle with the Mamprusi in the aftermath of its report. The Mamprusi and the Kusasis thought differently about the composition of the committee. While the Mamprusi described the Committee as a political tool of the C.P.P., the Kusasi saw it as the best any government could do. The Mamprusi thus declared the Committee as one lacking neutrality. The Opoku-Afari Committee was thus expected to do the bidding of Nkrumah's political agenda. A Mamprusi interlocutor, for instance, explained the partisanship of a member as below:

Lure Kanton III was but clay in the hands of Nkrumah who could mould him into anything he wanted. He openly supported Nkrumah and even campaigned against his brother, Alidu Kanton, who was then the incumbent member of the Legislative Assembly, just to ensure that his boss' (Nkrumah's) choice Imoro Egala won the seat in the 1954 election. $^{27}$

Two participants (a Kusasi and the director of an NGO), though admitted the partisan nature of the Committee, justified it on the grounds of lack of cooperation among the political parties when they said:

There is the tendency to criticise Nkrumah and the Governor for the partisan nature of the Committee. But considering the tension between the C.P.P and the other opposition parties particularly the U.P. and the N.P.P, how could the government have confidently relied on the members of the opposition for such a sensitive exercise. Even today, after years of democracy, which political party in this country would have adopted a multiparty approach to the problem. To say that just because they supported C.P.P they could not have been neutral amount to saying that they couldn't use their senses and experience. ${ }^{28}$

Furthering their disapproval of the committee, the Mamprusi argued that the Committee constituted a political interference in what was a purely traditional affair, especially as the Nayiri had already taken steps to resolve the impasse (NRG8/2/138) ${ }^{29}$ They further accused Nkrumah of fuelling conflicts in the whole of north-eastern Ghana.

\footnotetext{
${ }^{27}$ Interview with Seidu Abagri.

${ }^{28}$ Interview with Agarba, Bawku, 16 September 2018. This interlocutor is a Kusasi, a teacher and has a bachelor degree Political Science. Also, interview with the director of Belim Wusa Development Agency (the NGO facilitating peace talks among the actors in the Bawku conflict, through the Bawku Inter-Ethnic Peace Committee established by the government of Ghana in 1999.

${ }^{29}$ Upper Region House of Chiefs (UHC) 85F. 4/129, letter from registrar to the Nayiri, $27^{\text {th }}$ Mar. 1972.

NRG8/3/82 letter No., Upper Region House of chiefs to the Nayiri, $27^{\text {th }}$ Mar. 1972.
} 
It must be admitted, however, that considering the exigencies of that time in a newly independent country coupled with the loss of lives and property, the government could not have done any better. Even after several years of independence, Ghana and indeed many other countries across the world including the mature democracies, use this same approach to calm down tension during such times. On the accusation of interfering in traditional affairs because the Nayiri had already taken steps to resolve the conflict, Nkrumah could be exonerated on the grounds of no trust between the Prime Minister and the Nayiri and that the Nayiri, a Mamprusi, might not be fair to the parties in conflict especially the Kusasi. This is not to doubt the competence of traditional rulers to settle conflicts. The government's decision to set up a committee to investigate the conflict was not peculiar to the Nkrumah regime. Subsequent regimes and in fact governments in Ghana have set up committees and peacekeeping on the Bawku conflict. However, the failed state intervention appears to have sown a seed of protraction, creating a permanent fraction between the major ethnic groups and their allies mired in hostile electoral politics.

\section{Key extracts from the committee report and their effect on the conflict}

The committee's report is punctuated by three broad issues that inhibit the potential for sustainable conflict resolution. First, it failed to engage the chronology of historical material on Bawku, Second, the report implied that the Bawku traditional area fell outside of the Mamprusi jurisdiction. Third, the report created a cultural dichotomy (othering), which described the Mamprusi kingmaking as one of compulsion while the Kusasi used a democratic approach.

On the first note, the committee appears to have concentrated only on some aspects of the history of Bawku which did not provide the right background to the pre-colonial relationship between the Mamprusi and Kusasi. Writing about the history of Bawku, the Committee reported: 
About 150 years ago, when the slave trade was still flourishing in the North, Na Atabea, the Nayiri of Mamprusi who lived in Nalerigu, his capital sent his son, Prince Ali, to establish a post at Bawku and guard the trade route between Nalerigu and Gambaga in the South and Tenkudugu and Wagadugu in the North. This was because the Kusasi who inhabited that area formed themselves into bands of robbers and burglars, way-laid and robbed Mamprusi traders going to the North with their wares or returning to the south with their slaves. DELETED

Also, the above extract implies that the establishment of the security posts by the Mamprusis was for the development of slavery in the area. It implies that Bawku was established to promote the slave trade. While it was true that Bawku was established to protect all trade routes in the district, the purpose was not for the protection of the slave trade. Many reasons explain this. First, as part of their proof of autochthony, the Kusasis claim that they invited the Mamprusi to Bawku to provide security for them (the Kusasis). Even at the time of conducting this study, the personal secretary to the current Bawkunaba repeated this claim. He narrated: We invited the Mamprusi to provide us security and this is an indication that we were occupying the land before they arrived' ${ }^{30}$. If indeed the security posts were for the promotion of slavery in the area as the extract suggests, then where lies the Kusasi claim of having invited the Mamprusi to provide security in the district. Furthermore, if the Mamprusi were involved in slave raiding and slave trading in the area, it is doubtful the Mamprusi would have been the choice of the Kusasi for the provision of security in the district. Finally, the Mamprusi princes were known to be more interested in providing security services and collecting transit tax commonly referred to as "Ferago" paid by traders for the security and escort services rendered by the Mamprusi. ${ }^{31}$ In those days, the transit tax was a common practice among successful Kingdoms like the Ghana Empire. At least Syme (the then Commissioner in the area) has captured Kusas involvement in the slave trade. While under the

\footnotetext{
${ }^{30}$ Interview with Azanga Abdulai, Bawku, 16 October 2018.

${ }^{31}$ Interview with Seidu Abagri. Also, a 65-year old Busanga man commonly called Baba in the Hausa Zongo, Bawku, 10/10/2018.
} 
protection of the Mamprusi, at least in Binduri and Sinnebega, the Kusasi bought slaves in transit for labour and wives. ${ }^{32}$ Syme added:

The children of the slaves bought by the Kusasi were invariably absorbed into the tribe known as Kusasi, and by the third generation, they would all bear Kusasi facial markings. It is not difficult to obtain corroboration for the above statement. At Zabugu, some four miles south of Bawku, there was until fairly recently a man called Agbenga Kusasi who bought a Bussanga named Akorli. This slave had many children by Kusasi women and many of them are still alive $(1-3)^{33}$.

According to Syme's evidence therefore, the Committee rather twisted the facts.

According to the report, the Kusasi formed themselves into bands of robbers and burglars, way-laid and robbed Mamprusi traders. This study, however, found that it was rather the Bissa and Chakossi who were harassing traders and raiding people including the Kusasi and selling them into slavery. ${ }^{34}$ This was what compelled $\mathrm{Na}$ Atabea to send his son to Bawku to halt the activities of the raiders and ensure the safety of the trade route in the district. This study also found that the wars between the Mamprusi and the Bissa were largely due to the Nayiri's anti-slavery activities in the area. For instance, the then chief of Teshie (a Mamprusi community in the then Bawku district), who was the closest Mamprusi chief to the Kusasi ancestral home was killed in the course of attempts to stop slave raiding in his area. ${ }^{35}$ Commenting on their relationship with the Bissa, a Mamprusi elder and opinion leader during an interview noted:

The wars we fought with the Bissa were due to slave-raiding activities of the Bissa. The Nayiri felt it was wrong and could not allow that to continue in his territory. In fact, the Bissa worried us. On one occasion they successfully infiltrated Bawku and murdered the Bawkunaba, Sateem. This left Bawku unprotected and the Bissa took advantage of the lack of security to enslave the Kusasi living in the area and sold them into slavery. ${ }^{36}$

\footnotetext{
${ }^{32}$ Syme, 'A Short', 1-3.

33 Ibid.

${ }^{34}$ Interview with Seidu Abagri. Also, Baba.

${ }^{34}$ Interview with Azanga Abdulai. Also, interviews with the chief of the Hausa Zongo, Adams, and Seidu Abagri.

35 Yirimea, 'A Short' page

${ }^{36}$ Interview with Seidu Abagri.
} 
This was corroborated by a Bissa interlocutor, who in the course of explaining BissaMamprusi relationship indicated as follows:

We used to fight the Mamprusi a lot. The wars we fought with them were all a result of the slave trade. Our people were very strong and were catching and selling people of other tribes who were operating in Bawku into slavery. The Kusasi in particular really suffered in this regard as we were catching them and selling them to slave buyers. $^{37}$

These responses resonate well with Syme's when he wrote: 'Busagas to the north and Zaberimies to the east considered all of them fair sport for periodical raids and the Kusasi generally seem to have come off worst in the encounters. ${ }^{38}$

Secondly, the committee's report about the Nayiri trying to rule a distant territory in Bawku from his base in Nalerigu, seems to have influenced the Kusasi advantage in claiming the Bawku paramountcy. Just as the president of a country can live in the capital of his/her country and yet have jurisdiction over all corners of that country, so could the Tosugu. After Gbewa's death, his son, Tosugu, moved to establish his capital in Zozugu with jurisdictional responsibility over the whole of Zotinga including Pusiga and Bawku' ${ }^{39}$. By the statement 'Na Atabea, the Nayiri of Mamprusi who lived in Nalerigu his capital' ( $p 2$.) the committee attempts to portray the Nayiri as being too far away from his subjects and Bawku, to claim and control Bawku as his territory. The report is thus an indictment of African civilization because it denies the existence of successful Kingdoms in Africa which had vast geographical spaces.

Thirdly, the report attempted to create a cultural dichotomy; one good and the other bad. The report indicated that while the Mamprusi appointed their chief, the Kusasi elected theirs,

\footnotetext{
${ }^{37}$ Interview with Azanga Abdulai.

${ }^{38}$ Syme, 'A short', IV.

${ }^{39}$ Yirimea, 'A History', 339-400.
} 
suggested the former practice is quite strange in the Kusasi land within which Bawku falls. This was captured in the report as follows:

The claimant contended that there is a great difference in the method of selection of a chief by the Kusasi and the Mamprusi respectively. According to him, the Kusasi use the free vote, and the Mamprusi use compulsion in the selection of their chiefs. The Kusasi believe in the free election of their chiefs whereas the Mamprusi believe in the appointment of chiefs to rule as military Governments do. ${ }^{40}$

This claim was not only invalid, according to long-standing customs. Rather, it created a cultural dichotomy between the Mamprusi and Kusasi. Some of the Mamprusi respondents construed this aspect of the report as Kusasi politicians' exploitation of the election of the Head Chief concept introduced by the British colonial administration after they introduced the indirect rule. Before the arrival of the British and the institution of election as a means of selecting chiefs in the North, the practice of chieftaincy was not by the Kusasi. The first three Kusasi chiefs were appointed at the request of the British colonial administration. ${ }^{41}$ Therefore, no Kusasi chief could have been elected before the arrival of the British in the north to make the election of chiefs part of a precolonial Kusasi culture. When the British colonialists arrived, they found that the Mamprusi had an established system of appointing chiefs, which was similar to what pertains in the rest of Ghana and other parts of Africa.

At best, therefore, the election of chiefs, which had no roots in African culture, is a colonial legacy. Furthermore, the Kusasi were known to be an acephalous group before the arrival of the British administration. Their acephalous past, therefore, meant that there could not have been the need for Kusasi to hold elections since there were no skins to vie for. To accept this claim of electing their chief is to redefine an acephalous group as a people with elected chiefs especially before the Indirect Rule of the British in the Gold Coast. In addition, if the election of chiefs was

${ }^{40}$ Committee report, 5-6.

${ }^{41}$ Yirimea, 'A History', 432. Also interview with Adams Abagri, Bawku, 16 October 2018. 
part of Kusasi culture, then the question would be, which of the Kusasi Bawkunabas were elected? Neither Abugrago nor his son (Aninchenma, the sitting Bawkunaba) was elected. Both were picked and appointed as Bawkunaba. The fourth extract even goes against the committee's claim that the Kusasi elect their chiefs. According to the report:

Abugrago gave evidence of his election and installation as Bawkunaba and the Head Chief of the Kusasi area. He claims to be the direct descendant of the former rulers of Bawku before the invasion by the Mamprusi. He claims that by customs the canton chiefs are appointed by the Bawkunaba in consultation with the elders and the counsellors of the particular canton and that he as Bawkunaba has recently appointed some chiefs according to custom. ${ }^{42}$ (Emphasis added).

The election of Head Chief referred to in the above claim took place only once in 1931. That election was requested by the British colonial administration and was conducted under the direct supervision of British officials. In that election there were only two contestants, Bawkunaba (Bugri Mamboda, a Mamprusi) and the Kusanaba (a Kusasi) and the canton chiefs were the eligible voters. Those two chiefs contested for the newly created British position of Head Chief of Bawku Traditional area. At the end of the election, Bawkunaba had a unanimous victory. Since neither Abugrago nor his father was a canton chief nor a royal to any of the 19 cantons, he could not and did not take part in that election. The other 18 canton chiefs, who together with the Bawkunaba formed the electoral college, did not surrender their independent status to the Bawku Skin after the election. Thus, the position of the Head Chief was purely the creation of the British, in 1931, for their administrative convenience and had no royal link whatsoever to the Bawku Skin ${ }^{43}$.

Therefore, the committee's report about the origin of 'Head Chief' came from the British colonial administration itself and had nothing to do with the customs and traditions of any of the ethnic groups in the area. Moreso, the election was a one-time affair and became unnecessary after

\footnotetext{
${ }^{42}$ Committee report, 4.

${ }^{43}$ Interview with Seidu Abagri.
} 
the Nayiri elevated the Bawkunaba to a Divisional Chief status and as a result became the automatic head of the canton chiefs.

\title{
How the Committee arrived at its report emerged: Key extracts from the evidence provided
}

The data suggests that the Committee wrote its report and recommendations based on two substances: the evidence of the history of the Bawku polity and the description of the Kusasi as indigenes and victims of long-standing Mamprusi rulership for decades. On the first dimension, the Committee wrote:

\begin{abstract}
Abugrago claims that his grandfather, Amalzum Zelbio was a Tindana, farmer and chief of Bawku before the European advent and the seizure of the Bawku Skin by the Mamprusi. He mentioned Amalsum Zelbio, Aguo Daa and Abadu as some of the Kusasi chiefs who ruled Bawku before the Mamprusi came and said that it was Abadu's time that the Mamprusi seized the Skin. The Mamprusi came along with the White man and were able to establish themselves on Kusasi land because of the influence and power of the White man. The Mamprusi had at the time come in contact with the White man and were familiar with him; the Mamprusi were the cooks and servants of the White man as well as his interpreter and policeman. The Mamprusi were more enlightened and appealed to the White man than the average Kusasi man. ${ }^{44}$
\end{abstract}

The British are known to have arrived in Gambaga in 1896 but they entered Bawku in 1907. Na Bariga was the Nayiri, the $21^{\text {st }}$ Nayiri. This means that twenty Mamprusi Kings had already ruled the area before the British colonialists arrived in Mamprugu. Furthermore, it is known that Bawku was founded by Na Atebea (the $10^{\text {th }}$ Nayiri) who ruled between 1690-1741/2. From 1742 to 1907 gives a clear period of about 160 years between the founding of Bawku and the arrival of the British colonialists. So, the Mamprusi could not have "come along with the White man" as claimed by Abugrago in the Committee's report. Thus, such description of the Mamprusi as agents of the colonialists could be part of the factors that provoked the Mamprusi who felt convinced that the

\footnotetext{
${ }^{44}$ Ibid.
} 
report was politically motivated. According to a Kumasi-based Mamprusi elder, they complained and expressed their objections about the composition of the Committee right from the onset. $\mathrm{He}$ said:

The very day the government announced the names of the members of the Committee our people had no confidence in it. They knew it was not going to be neutral. How can a Committee made of such mature and experienced people claim that the Mamprusi came to Bawku together with the White people? We foresaw it and the Committee's report was a kind of a prophecy fulfilled. ${ }^{45}$

It is possible that the busy nature of the offices of the Governor-General and his prime minister, Nkrumah, might not have allowed them to read the full report but rather trusted the Committee and implemented its recommendations to reduce the volatility of the situation. Also, if the government had not implemented the Committee's report and instead had shelved it as it is the character of even contemporary multiparty governments in Ghana and beyond, the conflict could have degenerated into something worse. A Kusasi sub-chief, in an interview, commented in passing saying: "Even without Nkrumah, our people were already prepared to fight till we got what rightfully belongs to us". ${ }^{46}$

That said, considering the delicate nature of the situation, the government could have sought the opinions of other prominent traditional leaders or even historians if they were not familiar with the history of the British colonial activities in Bawku. Also, the Committee with two prominent chiefs, should have further propped the claim that the British played a role in founding Bawku, which had over a hundred years of Mamprusi rulership before the advent of colonial rule in the area, as captured in the colonial records and writings of Rattray and Syme who were the first to research into the customs and culture of the people.

\footnotetext{
${ }^{45}$ Interview with Adam Abagri.

${ }^{46}$ Interview with Azanga Abdulai.
} 
According to the report, Abugrago claimed that: "The Kusasi were then not well organized and could not resist the peaceful invasion of the Mamprusi supported by the White man. Thus, the Skin of Bawku was seized from his grandfather and given to the enlightened Mamprusi". ${ }^{47}$

From the field interactions and interviews, it became obvious that Zotinga covered a large territory of fertile land. It was economically a strategic area and an important trade route, especially during the slave trade era. ${ }^{48}$ Many wars were fought in the area involving the Bissa, Zambrama and the Chakossi ${ }^{49}$. For instance, in course of explaining why the Bissa fought several wars with the Mamprusi, a Bissa interlocutor stated:

Most of my people settled in the peripheral areas commonly known as the Bissa-Belt due to the fertile lands in those areas. We are farmers and we even introduced metal farming tools in this area. But we didn't fight the Mamprusi because of the fertile lands, rather due to them obstructing slave trade activities in the area in those days. But those were the days. We are one people. No more war. ${ }^{50}$

Syme wrote, "Kusasis, dotted about the place, lived in comparative peace" (2). Juxtaposing Syme's description of the Kusasi as people dotted about on Abugrago's own admission that they (the Kusasi) were then not well-organized, how could they have been able to establish an area like Zotinga and ruled it without fighting any war against any of the aforementioned groups at least to defend the area? ${ }^{51}$ Moreover, Abugrago claimed that because they were not well organized, they could not resist the peaceful invasion of the Mamprusi. This claim contradicts Kusasi claim that they invited the Mamprusi to Bawku to protect them. The statement, "Thus the Skin of Bawku was seized from his grandfathers and given to the enlightened Mamprusi" ${ }^{252}$ implies that the British

\footnotetext{
${ }^{47}$ Committee report, 4.

${ }^{48}$ Interviews with Azanga Abdulai, and Seidu Akalifah.

${ }^{49}$ Bissa,Zambrama and the Chakossis are ethnic groups in northern Ghana. This is not to say that they cannot be found in other parts of the country.

${ }^{50}$ Interviews with Azanga Abdulai.

${ }^{51}$ Syme, 'A Brief', 2.

${ }^{52}$ Committee report, 4.
} 
seized the Bawku Skin and handed it over to the Mamprusi. This further implies that Mamprusi rule in Bawku is a recent affair or it began after the arrival of the British in Bawku.

If indeed Abugrago claimed that the British seized the Bawku Skin from Abadu to the Mamprusi, then the important question is: how come the British, nor the anthropological research report of Rattray, never documented such as important invasion or show any knowledge of Abadu's reign in such as important area? At least, colonial literature such as Syme's and Rattray's would have captured it, even if just a portion of it. Historical records and history of ancient kingdoms and states exist for verification and references even today. The history of the Ghana Empire, Mali, Moshi, Mamprugu, Asante among others exist and can be traced as far back as their founders. Surprisingly, not even the history of Abadu whom the British were alleged to have met exists for verification. Again, Abugrago claimed that his grandfather was chief before the Mamprusi arrived in Bawku. Any neutral and non-politicised committee should have had Abugrago prove this claim by showing the committee at least where his grandfather first settled in Bawku when he arrived. He should have also been made to show where his grandfather's palace was located, for how long he ruled, and even some of his elders who supported him in ruling his subjects. The report was silent on any of these. ${ }^{53}$ The Kusasi themselves have no such evidence. During an interview with a Kusasi prince, he mentioned Amalgu as one of their grandfathers who ruled Bawku before the Mamprusi arrived. ${ }^{54}$ However, he had no idea where the grandfather lived, his skin name, how long he ruled, or the name of one of the elders he ruled within such an important area in the history of the Upper East Region of Ghana. Such lack of knowledge or deliberate refusal

\footnotetext{
${ }^{53}$ Historical records show that seven successive Bawkunabas had passed before the arrival of the British in 1907 when Mahama II was the substantive Bawkunaba. If so, how can Abugrago's claim that Agua Daa and Amalsum Zellbion ruled Bawku before the alleged arrival of the Mamprusi and the British be authentic and acceptable to the Committee whose membership had two important chiefs and the history known to the British?

${ }^{54}$ Edward is a Kusasi prince and the Headmaster of a senior high school in the study area.
} 
to give information or genuine absence of such information on their great-grandparents gives credence to the view that the most elderly Kusasi to have ever entered Bawku was Abugrago's father, Azoka. While this study finds nothing wrong with naming institutions after great people or those who have significantly contributed to the development of a people and or their community, this could be why the Kusasi use the name "Azoka" for their institutions. The first Kusasi Bawkunaba had a skin name Azoka I. The current one (who is the second Kusasi Bawkunaba) is also called Azoka II. The secondary school built by the Kusasi in their area is also named after Azoka. Finally, the political tag of the NDC's party guards is known as the Azoka boys.

Although the state remains indispensable if this conflict is to be permanently resolved, subsequent governments have not been able to depart from the aclaimed skewed report. Rather, they had shown a lack of political will to implement any meaningful decisions. During former President John Kufuor's reign (2001-2008), huge resources were invested into this conflict through the National Peace Council. What has become of that report? An interlocutor concluded: "President Kufuor only wasted national money on us and the National Peace Council. Hotel accommodation, food, allowance for several days, all gone wasted. Nothing came out of it. Where is that report? No government commitment!"55 Indeed, interventions by some post-colonial governments rather polarised the conflict, making it protracted. As a result of the over politicisation of the conflict, local people do not trust the national government to solve the crisis. Mutual suspicion between the Mamprusi and the Kusasi makes them not have high-level of trust in the non-governmental organisations either, albeit NGOs claim to be neutral actors. This makes Bawku still volatile. Each ethnic group has become so cynical and distrustful that there is a buildup of reciprocal negative images, which is perpetuating antagonism and solidifying the conflict.

\footnotetext{
${ }^{55}$ See footnote 8.
} 


\section{Conclusion}

The study set out to examine the details of how the first state intervention in the Bawku conflict has contributed to the conflict recurrence. In doing so, the authors interrogate the Opoku Africa Committee report which provided three key dimensional explanations of the Bawku conflict that would have contributed to the conflict protraction and limited potential for peacebuilding. These include an apparent failure by the Committee to engage some important historical material on Bawku; the report's portrayal of Bawku to be outside of Nayiri's jurisdiction; and the creation of a cultural dichotomy (othering), which described the Mamprusi kingmaking as one of compulsion while the Kusasi used a democratic approach.

Although Committee's report is rooted in the evidence the Kusasi being indigenes in Bawku and victims of long-standing Mamprusi rulership for decades, the data coupled with existing literature indicates that Nkrumah saw an opportunity to accomplish his agenda of neutralising the influence of the Nayiri and to destroy the strength of the Northern People's Party in the North, as part of C.P. P's grand agenda of winning power with a clear political dominance in the north. The inquiry thus manipulated the conflict for political gain. This provoked further conflicts between the Kusasi and Mamprusi and courted more partisan infiltration in the conflicts, affecting peacebuilding efforts altogether. The conclusion that the first state intervention could largely be blamed on the complexity and protraction in the Bawku conflict, reflects copiously in the literature. ${ }^{56}$ However, these accounts fail to adequately investigate the three critical dimensions

\footnotetext{
${ }^{56}$ E. Bombande, "Conflicts, civil society organizations and community peace building practices in Northern Ghana." In Ethnicity, conflicts and consensus in Ghana. Tonah, S. (Ed.) (Woeli Publishing Services, Accra). (2004). Pp: 196228; K. N. Bukari 'Exploring indigenous approaches to conflict resolution: The case of the Bawku conflict in Ghana.' Journal of Sociological Research, 4:2 (2013), 86-104.
} 
of how Nkrumah's intervention rather turned out to be a curse on the potential of the Bawku peace process.

This article has illustrated the specifics of what many accounts have indicated without details. This enables scholars and policymakers to appreciate the little spaces from which the Bawku conflict remains one of the most intractable in Africa. This helps to transcend the oftgeneralized understanding of state culpability in the Bawku conflict to engage the angles that produce the general assertion. Thus, while future academic discourse will engage and expand each of the triad aspects of the conflict protraction as emanated from the Committee report compared to existing theories and concepts, NGOs and policy discourses will be more interested in community engagement and advocacy in ways that tackle these issues that seriously inhibit sustained peace processes for many decades. 